\title{
Waste Picker Organizations and Their Contribution to the Circular Economy: Two Case Studies from a Global South Perspective
}

\author{
Jutta Gutberlet $^{1, *}$ (D), Sebastián Carenzo ${ }^{2}$ (D), Jaan-Henrik Kain ${ }^{3}$ (D) and \\ Adalberto Mantovani Martiniano de Azevedo ${ }^{4}$ \\ 1 Department of Geography, University of Victoria, P.O. BOX 3060, STN CSC, Victoria, BC V8W 3R4, Canada \\ 2 CONICET, Instituto de Estudios sobre la Ciencia y la Tecnología, Universidad Nacional de Quilmes, \\ Buenos Aires, B1876XD Bernal, Argentina; sebastian.carenzo@unq.edu.ar \\ 3 Deptartment of Architecture and Civil Engineering, Chalmers University of Technology, \\ Division of Urban Design and Planning, SE-412 96 Gothenburg, Sweden; kain@chalmers.se \\ 4 Center of Engineering, Universidade Federal do ABC (UFABC), Modelling and Applied Social Sciences, \\ Av. dos Estados, 5001—Bangú, Santo André, SP 09210-580, Brazil; adalberto.azevedo@ufabc.edu.br \\ * Correspondence: gutber@uvic.ca; Tel.: +1-250-472-4537
}

Received: 8 August 2017; Accepted: 23 September 2017; Published: 27 September 2017

\begin{abstract}
The discussion on the circular economy (CE) has attracted a rising interest within global policy and business as a way of increasing the sustainability of production and consumption. Yet the literature mostly portrays a Global North perspective. There is a diverse spectrum of community-based organizations playing important roles in resource recovery and transformation, particularly, but not only, in Global South countries, providing innovative examples for grassroots involvement in waste management and in the CE. This article proposes to add a Southern lens, situated in the context of waste picker organizations, to the concept of CE. The discursive framework in this article couples ecological economy (EE) with social/solidarity economy (SSE), focusing not only on environmental sustainability but also on social, economic, political and cultural dimensions involved in production, consumption and discard. We acknowledge that grassroots movements contribute to policy making and improve urban waste management systems. The paper outlines two empirical studies (Argentina, Brazil) that illustrate how waste picker organizations perform selective waste collection services, engage with municipalities and industries, and practice the CE. The research reveals that social and political facets need to be added to the debate about the $\mathrm{CE}$, linking environmental management and policy with community development and recognizing waste pickers as protagonists in the CE. Our findings emphasize a need for a change of persisting inequalities in public policy by recognizing the importance of popular waste management praxis and knowledge, ultimately redefining the $\mathrm{CE}$.
\end{abstract}

Keywords: circular economy; Global South; waste pickers; reverse logistics; solidarity economy

\section{Introduction: Circular Economy Perspectives}

The idea of a circular economy (CE) has attracted a rising interest in global policy and business during recent years, to increase the sustainability of production and consumption [1-3]. Although the $\mathrm{CE}$ concept has similarities with the more widely used concept of sustainability, these two concepts cannot be conflated since $\mathrm{CE}$ is usually seen as a necessary but not exclusive element of sustainability [4]. The CE concept has multiple roots and interweaves with many parallel lines of thought, such as ecological economy, general systems theory, industrial ecology, regenerative design, performance economy, cradle to cradle, and biomimicry $[2,5,6]$. There is "a fixed number of atoms currently formed 
into today's products that should be repeatedly reorganized into future products without requiring any further injection of new atoms" ([7] p. 446). With its focus on waste, CE is often summarized as the 3Rs (reduce, reuse, recycle) or different variations of the more ambitious 6Rs (e.g., reuse, recycle, redesign, remanufacture, reduce, recover) [6].

Although the CE concept is now emerging as a major topic in global policy and research, it had a significant impact on Chinese national policy and research already in the early 2000s e.g. [8,9], inspired by German and Japanese recycling policies to deal with the depletion of natural resources, the degradation of ecosystems, and pollution linked to accelerating industrialization [10]. During the last 10 years, the Chinese focus in CE has remained strong, and there is an increasing interest among European researchers while US research seems to lag behind [11].

Even if European waste policies from the 2000s can be seen as inspiration for CE in other countries [10,12], the globalization of the waste trade redefines resource relationships between the Global North and the Global South. Today countries and regions are intrinsically linked and interrelated through waste and resource flows in both directions, not least in a global system of resource recovery from waste [13]. In consequence, the CE concept is highly relevant for countries in the Global South.

Emerging CE policy initiatives in the Global North define its challenges mostly in terms of how to improve engineering and governance aspects of resource loops [4]. Yet from a Global South perspective, another issue becomes key: the social inclusion of large populations that still live in poverty and marginalization [14], as well as including improved participation on the formulation, implementation and evaluation of public policies related to waste management (waste governance). Thus, within the field of waste management, this implies that, when further developing a CE framework, there is a critical need to consider how to include waste pickers that have a long history of coping with resource scarcity through different types of resource recovery activities based on socioeconomic necessities [14]. As Velis [14] points out, the CE imperative brings both challenges and opportunities to such an ambition. It is not evident that the current CE emphasis on capitalistic business models sits well with ambitions to decrease core inequality issues related to access to resources and working conditions. Here, the latent opportunities of CE for more equity-oriented business models need to be further explored and realized [14].

The main idea studied in this article is how the current CE perspective needs to be amended by taking into account the insights developed by, and collected from, initiatives by informal and organized waste pickers from the Global South performing activities that benefit both the environment and society. The article addresses the challenge of expanding the social and political aspects of the CE concept (making social benefits more sustainable and less paternalistic), by applying a Southern lens, situated in the context of waste pickers. We introduce ecological economy (EE) and social/solidarity economy (SSE) as a combined theoretical framework which helps us understand the multiple facets involved in CE. We describe two empirical studies (Argentina and Brazil), where we have conducted participatory action research, to highlight the vital contributions of waste pickers to an expanded notion of CE. Finally, we discuss how these two cases support the argument for a redefinition of the CE by adding social and political dimensions to the concept.

\section{Theoretical Framework: Linking the Social/Solidarity Economy with the Ecological Economy}

Ecological Economy (EE) focuses on the interdependence between human economy and ecosystems. A key contribution to the discussion is the theoretical framework developed by environmental economists Pearce and Turner [15], based on the laws of thermodynamics and inspired by the 1966 essay "The economics of the coming spaceship Earth", by Kenneth Boulding [16]. In contrast to seeing economy as a linear and open system (take-make-dispose), CE sees economy as a closed and circular system, where waste is a primary resource for production. Although the concept of $\mathrm{CE}$ is central, EE also includes urban metabolism and industrial ecology, as well as discourses focusing on sustainability, regeneration, resilience, de-growth and zero waste $[17,18]$. EE engages 
with unorthodox ideas of democracy, economy and society [19], and also with non-capitalist political practices [20] belonging to "transition discourses" that call for significant paradigmatic or civilizational transformations [21,22]. While centering on the integration of ecological, social and economic goals, EE is based on principles of responsibility, precaution, adaptive management and participation, seeking for sustainable governance.

Social and solidarity economy (SSE) centers on everyday practices of alternative ways of living, producing, and consuming [23]. It discusses sustainable livelihoods, social enterprises, heterodox approaches to economy, participative policy formulation and decent working conditions, by highlighting the social and human assets dimension and considering diverse forms of collective organization, such as cooperatives, networks, and unions [24-28]. Based on values of solidarity, autonomy, cooperation and reciprocity, SSE seeks non-capitalistic economic relations and forms of grassroots socioeconomic organization to transform hierarchical and authoritarian models and operations $[29,30]$. SSE particularly privileges those segments of society which have been historically marginalized, discriminated against and politically, socially and economically excluded. Often community-based organizations and social movements are embedded in the social/solidarity economy (SSE). In this way, SSE also comprises a set of survival strategies developed by marginalized social sectors and non-capitalist cultures.

Dinerstein [31] suggests SSE as a tool for organizing hope; a practice that enables people to anticipate alternatives-future practices, relationships and horizons-in the present, guiding concrete actions. The SSE framework also supports the formal development of policies and theories that can support collective approaches, for example, as those trailed by the members of the recycling cooperatives portrayed below. Reciprocity is expressed through mutualistic approaches of collective ownership by members of a cooperative or other form of collective association, for their own benefit and that of the wider community. The following figure shows the discursive framework applied to our discussion, briefly characterizing the EE and the SSE (see Table 1).

Table 1. Combined discursive framework of ecological economy and social and solidarity economy. Based on $[23,32]$.

\begin{tabular}{ccc}
\hline Environment/Society & Ecological Economy & Social and Solidarity Economy \\
\hline $\begin{array}{c}\text { Ecological and cultural } \\
\text { creation }\end{array}$ & $\begin{array}{c}\text { Sufficiency in energy and natural } \\
\text { resources use }\end{array}$ & The commons, collective ownership \\
\hline $\begin{array}{c}\text { Production of goods and } \\
\text { services }\end{array}$ & $\begin{array}{c}\text { Reuse, recycling of materials, use of } \\
\text { renewable energy, etc. }\end{array}$ & $\begin{array}{c}\text { Grassroots organizations, worker and } \\
\text { producer cooperatives, networks, etc. }\end{array}$ \\
\hline $\begin{array}{c}\text { Exchange and transfer of } \\
\text { resources }\end{array}$ & $\begin{array}{c}\text { Green taxes, elimination of } \\
\text { agricultural and energy subsidies, etc. }\end{array}$ & $\begin{array}{c}\text { Fair trade, gift economy, community } \\
\text { currencies, solidarity markets, collective } \\
\text { commercialization, etc. }\end{array}$ \\
\hline Consumption/use & $\begin{array}{c}\text { Efficient transportation systems, } \\
\text { organic agriculture, biomimicry, etc. }\end{array}$ & $\begin{array}{c}\text { Consumer cooperatives, housing } \\
\text { cooperatives, ethical consumption, etc. }\end{array}$ \\
\hline Surplus allocation & $\begin{array}{c}\text { Resource recovery, environmental } \\
\text { protection, etc. }\end{array}$ & $\begin{array}{c}\text { Community financing, credit unions, } \\
\text { cooperative banks, microcredit, etc. }\end{array}$ \\
\hline
\end{tabular}

Both EE and SSE draw the attention to innovative forms of economic interactions, where both people and the environment matter, transcending profit generation, efficiency orientation, and paternalistic practice [29]. The combined discursive framework is appropriate for understanding the practices of waste pickers organized in cooperatives, associations, networks, unions or other forms of collective arrangements. Such activities fit well under both SSE and EE frameworks as they pursue guiding principles involving bottom-up, grassroots and community-based initiatives, and as their activity contributes to material recovery that reduces the waste of natural resources [33]. Community-level organizations, such as waste entrepreneurs [34] and recycling cooperatives, play vital roles in practicing small-scale CE by linking environmental management with community development [35]. 


\section{Methodology}

The data discussed in this article has been collected as participatory action research (PAR) conducted with waste pickers in Buenos Aires, Argentina, and in the metropolitan region of São Paulo, Brazil, between mid-2016 and mid-2017, as part of two ongoing collaborative research projects, led by the authors and involving local waste picker groups and other local actors. PAR is "a process in which people (researchers and participants) develop goals and methods, participate in the gathering of and analysis of data, and implement the results in a way that will raise critical consciousness and promote change in the lives of those involved-changes that are in the direction and control of the participating group or community" ([36] p. 187). Our research takes a long-term collaborative and transformative approach, pursuing practical solutions and change together with the research participants [37]. Trust between the authors and the research participants had been built through previous research interventions over the past five years.

The relevant data was collected during regular visits of the researchers to the recycling cooperatives. In-depth conversations (individual and group interviews) with leaders from these waste picker groups were recorded and later transcribed. The researchers also took notes during meetings with other stakeholders in the case study area (local government officials and industry representatives), and examined official documents related to the cases studied (e.g., reports, memos, and published news from the local press). We applied a qualitative content analysis to the collected data to support the discussion and redefinition of the CE in this article [38]. Our approach to research is reflexive, seeking transparency and ongoing input from the participants to check, update and verify results and data interpretation.

\section{Everyday Experiences in Working with the CE}

The following two empirical studies aim to illustrate the importance of the work of informal and organized waste pickers for the CE.

\subsection{The Experience of Coopcent-ABC with Contracts under Reverse Logistics}

Coopcent-ABC (Coopcent) is a second-degree cooperative that organizes a network of waste picker cooperatives in the state of São Paulo, Brazil. Established in 2007, Coopcent currently supports 12 waste picker cooperatives in different municipalities, all of which have representatives on Coopcent's board of directors, oriented towards solidarity economy practices (Gutberlet, 2015a). The network was formed originally to assist cooperatives in collective commercialization. Gradually, Coopcent diversified its mandate to include political activities, such as: dialogue with the national recyclers' movement (Movimento Nacional de Catadores de Materiais Recicláveis-MNCR), negotiations with municipal governments and other waste management policy formulators, promotion of environmental education campaigns, and negotiation with public and private large waste generators. Thus, Coopcent may be seen as a meta-association between its affiliated cooperatives, with a potential to perform activities aligned with an enhanced view of the CE. However, as we will see in the empirical study outlined here, there are many challenges for such a performance.

In 2016, Coopcent initiated a collaboration with the industry association ABIHPEC (Associação Brasileira da Indústria de Higiene Pessoal, Perfumaria e Cosméticos), signing a two-year agreement under the project "Dê a mão para o futuro: reciclagem, trabalho e renda". This project was designed to help ABIHPEC associates to comply with the National Policy on Solid Waste (PNRS Política Nacional de Resíduos Sólidos) proclaimed by the Federal Government in 2010. Under this project specific agreements were negotiated for participatory strategic planning with all cooperatives.

According to the PNRS, large waste generators have to create reverse logistics systems by means of sectoral agreements, or specific regulation. In 2012, the Ministry of Environment launched a public call to select proposals of reverse logistic systems for the packaging industry (producers, importers, distributors and marketers). ABIHPEC and other sectoral associations applied with a proposal in 2013. 
Their proposal was approved and put up for public consultation in 2014. The sectoral agreement was signed in 2015 by 20 associations and federal authorities. ABIHPEC and their associates launched their projects aiming at the municipalities listed within the agreement.

As for Coopcent affiliated cooperatives, ABIHPEC's responsibilities include environmental education initiatives, purchase of equipment and infrastructure and contracting of advisory and professional development services. As a response, cooperatives have to increase resource recovery over a three-month period (in some cases an increase between $15 \%$ and $25 \%$ ). ABIPHEC must ensure that their initiative will recover a volume and weight of waste equivalent to the established goal ( $22 \%$ reduction until the end of 2017). The cooperatives also have to destroy the packages in order to avoid product piracy.

Five consultants from the waste picker association in the west of São Paulo, ARCOP (Associação Regional de Catadores do Oeste Paulista), were contracted to implement advisory and professional development services, including professional development courses, equipment maintenance and assistance. Equipment and infrastructure is being purchased on the basis of price taking and quality assessment, and from suppliers collaborating with ABIHPEC. All cooperatives affiliated to Coopcent received infrastructure investment, office equipment, computers and production equipment. The case study points towards the following three learning aspects:

1. Cooperatives face difficulties with the contracting and purchase proceedings (project implementation), having to fulfil a number of complicated and time consuming bureaucratic conditions which sometimes jeopardize the purchase or maintenance of equipment (e.g., the purchase of goods and services from suppliers which do not have previous contracts with ABIHPEC). Also, contracting and purchase are centralized by ABIHPEC, which controls the funds and allows for little participation of cooperatives in the decision-making processes. Giving cooperatives flexibility to act according to their needs, moreover, shared decision-making would be a more democratic way to perform the project. The fact that ABIHPEC currently develops projects with 129 cooperatives in eight Brazilian states certainly creates the need to adopt standard procedures and contracts, and the need to deliver accountability to companies associated is likely to make procedures less flexible and adaptable.

2. Another difficulty is that many of the machinery and all spaces where Coopcent affiliated cooperatives operate are of municipal property, which makes it difficult to implement structural changes that need to be authorized by municipal authorities. All projects must include covenants with municipalities, committed to provide and maintain buildings for the cooperatives. In some cases, delays on required maintenance that could be made by ABIHPEC overlap with municipal responsibilities, precluding project evolution. In addition, in some cases access to municipal authorities is difficult for cooperatives representatives.

3. Finally, in our evaluation, individual terms of agreement with cooperatives should be designed to be more flexible on implementation, adaptable to changing circumstances on operating conditions, whether these changes are challenges or opportunities, assuring that the voices of waste pickers are heard in decision-making processes, valuing their knowledge (particularly regarding their own needs). More than an improvement on agreements management, this could mean better governance of the tripartite public/private/cooperative partnership itself, giving more decision power to cooperatives and making decision taking processes more democratic, adding to the environmental sustainability and economic efficiency dimensions of the CE and the political principles of solidarity economy (self-management, shared decision-making and people empowerment). Participative contract formulation through strategic planning meetings has been a positive element, but the implementation is still difficult, calling for more agility and flexibility.

\subsection{The Experience of Reciclando Sueños Cooperative with the Large Waste Generator Limpex Industry}

Since mid-2012 waste picker cooperatives were invited to elaborate a new regulatory framework for waste management, promoted by governmental authorities, OPDS (Organismo Provincial para el 
Desarrollo Sostenible), in Buenos Aires, Argentina, and focusing on large generators (LG) producing more than 1 ton/day of waste, such as malls, private urbanizations, commerce, and industries. By the end of 2013, OPDS launched ordinances No. 137-138-139, establishing a set of legal and fiscal prescriptions to both, cooperatives and LGs. The aim was to foster the former to commercialize the provision of specialized waste management services to the latter. A key formative issue of the whole process was given by the fiscal and legal formalization support provided by OPDS. Through this formalization, the coops could issue an official certificate in which they stated the total amount and type of materials taken from LG and then re-introduced into the productive circuit as factory supplies from recyclable sources. Importantly, this document is key for LGs to attaining environmental and social licenses (e.g., ISO 14001). The cooperatives also benefitted, as for the very first time, they were able to issue an official document under the same conditions as private waste management companies operate.

Within this arrangement, the waste picker cooperative Reciclando Sueños was contacted by a global corporate chemistry industry called Limpex with headquarters in the US. For several decades Limpex has developed its business in a linear fashion, including the dumping of all their waste without any form of separation of recyclables. In the past, they had contracted a corporate waste service provider, charging up to US $\$ 70 /$ ton to take their waste out and dump it at the landfill. Notwithstanding, in recent years the company strategy (at both global and local levels) had become more sensitive to addressing social and environmental goals, for example, exploring ways to tackle the CE perspective within the operation of their plants and by promoting the recyclability of its overall waste production.

In July of 2016, a contract between Reciclando Sueños and Limpex was signed. The former contract between Limpex and the corporate waste service provider had to be revised in order to include the cooperative under the same conditions and role. This was not an easy decision considering the corporate culture custom and habits at Limpex, where breaking down a contract that seemed to work well could be considered as something abnormal. Still, Limpex had a strong motivation to do so. Basically, they could save money, as the cost for managing their recyclables plummeted from US $\$ 70 /$ ton (corporate) to US $\$ 15 /$ ton (cooperative). Also, as the cooperative's service included more items to be treated, they doubled their recyclability rates, aligning their local facilities with global corporate standards. Moreover, Reciclando Sueños added more than 20 tons/month of recyclables to its operation, where recyclables represent their current main income. This contract became a milestone in their struggle for recognition as a public service provider, shaped by sustainable social and environmental waste management standards.

However, the process was not a fairy tale. It took three years of harsh negotiations, in which the participants faced several obstacles. Consequently, we can derive some useful learnings:

1. To be able to count on a public policy regulatory framework was key, but not enough. During the process of becoming registered as Limpex' service provider, some gaps emerged in relation to the cooperative's fiscal and legal situation. To resolve this bottleneck specific technical support was required which was finally financed by Limpex. Including a cooperative within a CE framework is hence not only a matter of willingness, it also implies to assist them in different ways to develop as service providers.

2. The definition of what is recyclable waste must include the waste pickers' perspective. At the beginning, the contract focused only on the treatment of food containers and polyethylene terephthalate (PET) bottles generated daily in the company's dining room. In this way Limpex could "include" the cooperative without jeopardizing their previous waste management service. However, as these materials represented less that 1 ton/month, the whole project turned economically unsustainable for the cooperative. At this point, Reciclando Sueños offered a counterproposal based on their own diagnosis of the company's waste streams. As a result, they identified a wide range of valuable materials to be included in the contract, which would have direct impact on the company's recyclability rates and result in lower costs per ton. 
These arguments were key to review the existing contract and include the cooperative as a major service provider to Limpex.

3. The role of waste pickers as service providers to LGs is not restricted to operational waste management. The current definition of $\mathrm{CE}$ basically tackles material flows and engineering procedures, while knowledge issues remain unconsidered. Yet one of the most outstanding findings of the Reciclando Sueños-Limpex experience is related to the flow of knowledge. While negotiating the contract, the members of the cooperative gave workshops to Limpex employees on recycling topics based on their experiences. As a result, the waste sorting system in the offices and on the shop floor increased up to $50 \%$ in efficiency.

\section{Discussion: Current Challenges with CE Systems Based on Everyday Experiences of Waste Pickers}

The following discussion focuses on two interrelated dimensions: (a) the need of a public policy framework aimed at recognizing waste pickers as specialized waste service providers not restricted to households, but also oriented towards large waste generators (e.g., industry, business, offices); and (b) the potential of the pedagogical skills of waste pickers that goes far beyond their current role as operational collectors and classifiers. In both dimensions, an enhanced CE perspective must include the participation of a network of stakeholders on the multi-level governance of waste management public polices, including formulation, implementation and evaluation. Here we consider what Hooghe and Marks ([39] p. 237) describe as an alternative concept of multi-level governance, "[ ... ] one in which the number of jurisdictions is potentially vast rather than limited, in which jurisdictions are not aligned on just a few levels but operate at numerous territorial scales, in which jurisdictions are task-specific rather than general-purpose, and where jurisdictions are intended to be flexible rather than durable".

Drawing on the two case studies we can derive some useful insights about challenges and opportunities when building CE systems outside the Global North. This is key since government authorities, non-governmental organizations (NGO's) and private stakeholders in developing economies tend to extrapolate conceptual models elaborated in the North as if they were a ready-to-use policy tool. One such example is urban planning, where North, and even colonial, planning ideas and systems are applied to Global South contexts without much consideration regarding their appropriateness [40]. Also for CE, it seems that little work has been done in order to adapt or reformulate its underlying ideas and assumptions according to varying political, social and cultural local contexts [14]. We will therefore focus on findings that can contribute to building an amended CE framework from a Global South perspective. Our two main findings overlap with some of the challenges outlined by Velis [14], recognizing that waste pickers are an integral part of the CE in the Global South, and that additional resources need to be mobilized in support of transformation efforts towards the $\mathrm{CE}$, since there clearly are limits of what unsupported and unorganized waste pickers can achieve regarding their contribution to this $\mathrm{CE}$.

\subsection{Inequality and Public Policy Challenges}

As is widely stated in the literature, the current CE model mainly aims to provide new "green" and "sustainable" business platforms directed at large industries that could invest in redesigning their engineering procedures to "close the loop" by recycling the energy and material flows they generate [1,2]. In relation to waste, this could be achieved through the design of products that reduce the consumption of raw materials [7] or by recycling their waste as supplies for new productive processes, as discussed in industrial ecology see e.g., [41]. In developing economies the latter is far more frequent, that is, by shaping business models in which several small and large private companies take part, basically as reverse logistic service providers [12].

As we could see in the examples from Brazil and Argentina, the CE framework creates opportunities to make room for organized waste pickers as specialized waste management service 
providers for large industries and commercial enterprises. However, this forces us to consider an issue that is often neglected: inequity. From a corporate perspective waste picker organizations would hardly be seen as providers of high quality services, but rather as expressions of some kind of subsistence economy. Furthermore, the private companies that currently run the traditional waste management service business (linear and focused on landfill disposal) could also profit from the circular wind of change, by setting up new greener business units and take advantage of financial and marketing resources which the waste picker cooperatives still lack. Such CE solutions may carry an attractive "status quo" sentiment for policy makers and private business by sidestepping critical social and socioeconomic issues [4]. Still, as Gregson et al. [13] point out, circular loops are not shaped only by technical economic and engineering issues, but by moral issues as well. The question is which actor can best provide a proper CE service in the Global South; a waste pickers' cooperative relying on aspects such as resilience, solidarity, reciprocity, cooperation and autonomy for their survival, or only a commercial firm, prioritizing short-term profit on a global market?

Consistent with Dururu et al. [35] the lessons learnt from Argentina and Brazil underline that any achievements in waste management towards a CE must embrace social inclusion perspectives, since $\mathrm{CE}$ is also about community development. Otherwise, there is a risk that the prevailing discussion on CE is framed through a narrow EE perspective, without including any SSE values and strategies. Such a development may result in new business opportunities mostly for those actors already enjoying advantageous positions through the traditional linear economy approach with few social considerations, undermining the fragile position of existing waste pickers who already perform CE [42]. It is therefore essential to develop and strengthen public policy frameworks clearly stating the role and contribution of waste picker organizations in the CE. As was the case with the OPDS's ordinances in Buenos Aires, their work as specialized waste management service providers should not only be recognized in regulatory texts, but also practical fiscal and legal tools should be provided, such as official certificates. The Brazilian case study demonstrates that well-intentioned external intervention attempts may not achieve the positive long-term impact if sufficient local capacity building is not prioritized. Waste pickers need to have the capacity to act as central players in decision-making processes, and also need sufficient flexibility to address the situated contexts of each cooperative [43-45].

\subsection{Knowledge and Recognition Challenges}

A second issue linked to performing not only a circular, but also an inclusive economy of waste management (attending to both EE and SSE) has to do with not restricting the contribution of waste picker organizations only to the operational side of waste management, for example, as collectors and sorters. To enhance their role as specialized service providers their expertise regarding practices and meanings related to responsible waste disposal and recyclability should be fully recognized and accredited. In countries, such as Argentina and Brazil, grass-roots organizations have developed with more than a decade of existence and experiences, embodying specific knowledge on both technical procedures and artifacts, socio-cultural representations and management models for waste [44,46-49].

Much of this knowledge also involves CE issues, as waste picker organizations have designed loops and productive chains of material fluxes by transforming waste into supplies of resources. Still, what may be even more relevant, although less recognized, is the pedagogical contributions when dissemination of this knowledge is performed by the waste pickers themselves. As is also argued by Ninacs and Toye [50], social entrepreneurs, such as waste pickers, are able to make full sense of recycling for ordinary people and can thus change fixed routines and habits (personal and professional) in a way that graduated professionals cannot achieve. This is critically important when trying to disseminate and raise awareness about a model (i.e., CE) that is an alternative to mainstream economic practices; a model that may strongly influence the way we produce, consume and dispose of our consumer goods. One example and clear empirical evidence of the effectiveness of such pedagogical 
work is the workshop that Reciclando Sueños ran for Limpex employees, which allowed the company to increase the efficiency of their waste sorting system in offices and at the workshop floor by $50 \%$.

\section{Conclusions: Proposing a Socially and Politically Inclusive CE}

Current understandings of EE build on the interdependence between the human economy and ecosystems, calling for paradigmatic and civilizational transformations. Our planet is facing challenges with climate change, biodiversity loss, overexploitation and scarcity of natural resources, population growth, poverty and social exclusion, affecting the survival of many species, including humans. SSE puts forward values and propositions of alternative ways of living, producing, and consuming and carries with it hope for transformational change of our social and economic relations in favour of a more just and sustainable society. Coupling these two concepts is a necessity given the social and economic disparities, particularly in the Global South.

Worldwide, waste pickers have engaged historically in resource recovery by retrieving materials from the waste stream. Organized in cooperatives, associations, unions or other forms of community-based arrangements they collect, sort, and reintroduce recyclables to the industry. Some of these groups add value, by transforming materials (e.g., plastic into pellets) or by generating new products from these materials (e.g., washing lines from PET bottles; paper pulp into building blocks). These groups also perform educational services, by communicating with citizens, schools, resident associations and industries about selective waste collection and recycling, contributing to environmental education and making industrial processes more environmentally efficient. As Marcelo, a recycler from Reciclando Sueños, once said: "Circular economy is what we have been doing during all our life".

Insights from the two case studies underline the premise that waste pickers have a long tradition in performing CE, and yet they are mostly not invited to participate as main protagonists in the implementation of the CE. Organized waste pickers are in the position of spearheading transformational change, and women in particular are central in these operations. We need to remember that gender equity is essential to achieving economic change [17]. With the majority of organized waste pickers being women, there is huge potential for gender equity. Current CE defined by the Global North lens has evolved from EE theories on urban metabolism, industrial ecology, systems theory, cradle to cradle, and others, understanding waste flows as resources circles to be captured and reintroduced, thus ultimately tackling sustainability (see Figure 1). The SSE theories propose alternative ways of living, producing, and consuming; collective forms of organization (cooperatives, unions, networks, etc.); community financing (microcredit, cooperative banks, etc.), fair trade and the focus on local development and ethical consumption, thus adding critically needed social and political facets to the CE concept.

In this article, we propose that not only the principles of responsibility, precaution, resilience, adaptive management and participation (as required by EE), but also the principles of solidarity, autonomy, cooperation and reciprocity (as promoted by SSE), need to be reflected in the everyday praxis of a CE for the Global South, and probably in other contexts as well. Therefore, we suggest to redefine and amend the "Mainstream Circular Economy" concept into a more complete framework that considers the learnings from the EE and the SSE alike, what we call "Amended Circular Economy" (see Figure 1). Undoubtedly there are uneven and differentiated debates on the CE in the Global North and the Global South, which have to be uncovered and discussed. Further stakeholder engagement in policy to address inequalities and knowledge flows are required. Redefining the CE is also relevant for the Global North, where the voices and knowledge of dumpster divers, waste pickers, small waste entrepreneurs and waste workers are equally ignored.

By all means, this article has only scratched the surface of this complex issue. Further research is required to learn more from grassroots innovations linked to waste management and other socioenvironmental activities. More relevant and efficient policy initiatives are needed to provide 
equal opportunities for such organizations and entrepreneurs to participate in, and contribute to, the $\mathrm{CE}$, and to recognize and remunerate the waste pickers for the services they provide worldwide.

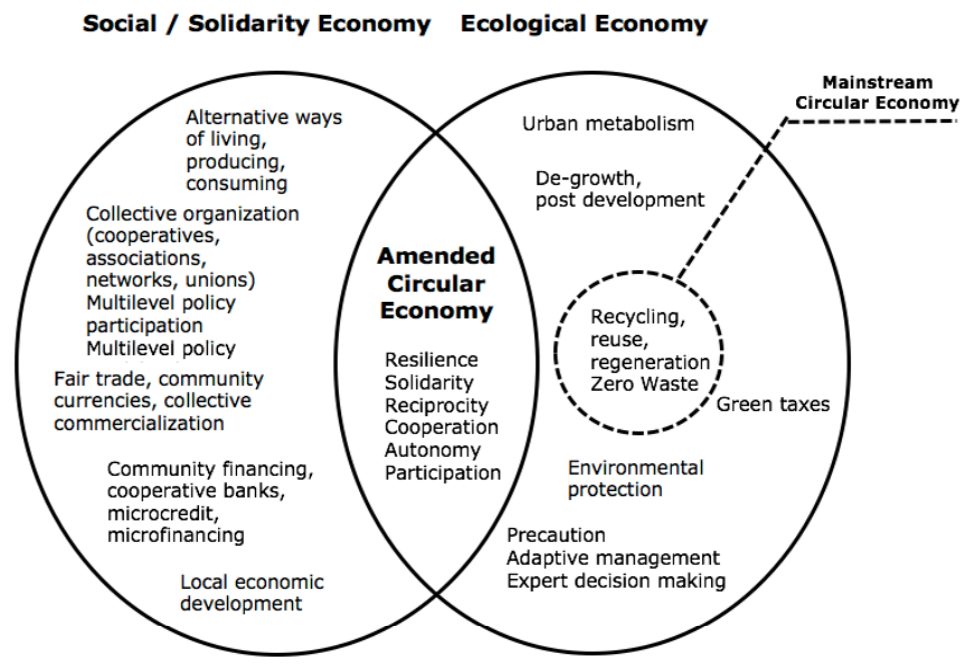

Figure 1. An amended framework for circular economy (CE) in the Global South (and elsewhere).

Acknowledgments: The authors recognize the vital input of the waste pickers to the research, without their knowledge and critical experience we would not have written this article. We are very grateful to the reviewers for their insightful comments and suggestions. Finally, we would like to acknowledge the funding agencies which have supported the empirical research (University of Victoria Internal Research/Creative Project Grant and the Swedish Research Council, grant reg. No. 2016-06289). Ethics approval has been granted by the Human Research Ethics Board at the University of Victoria, with the protocol Number 16-320.

Author Contributions: All four researchers involved in this paper are part of two on-going research projects, Jutta Gutberlet, Sebastián Carenzo and Adalberto Mantovani Martiniano de Azevedo have participated in the fieldwork conducted either in Buenos Aires or in Sao Paulo. Jutta Gutberlet, Sebastián Carenzo, Jaan-Henrik Kain and Adalberto Mantovani Martiniano de Azevedo have collectively analyzed the data and written this paper in a co-authored practice. Jutta Gutberlet took the lead in structuring and coordinating the production. We feel that all authors have substantially contributed to the work reported here.

Conflicts of Interest: The authors declare no conflict of interest.

\section{References}

1. European Commission. Towards a Circular Economy: A Zero Waste Programme for Europe; European Commission: Brussels, Belgium, 2014.

2. Ghisellini, P.; Cialani, C.; Ulgiati, S. A review on circular economy: The expected transition to a balanced interplay of environmental and economic systems. J. Clean. Prod. 2016, 114, 11-32. [CrossRef]

3. Stahel, W.R. The Circular economy. Nature 2016, 531, 435-438. [CrossRef] [PubMed]

4. Geissdoerfer, M.; Savaget, P.; Bocken, N.M.P.; Hultink, E.J. The Circular Economy: A new sustainability paradigm? J. Clean. Prod. 2017, 143, 757-768. [CrossRef]

5. Ellen MacArthur Foundation. Towards the Circular Economy: An Economic and Business Rationale for an Accelerated Transition; Ellen MacArthur Foundation: Cowes, UK, 2013.

6. Winans, K.; Kendall, A.; Deng, H. The history and current applications of the circular economy concept. Renew. Sustain. Energy Rev. 2017, 68, 825-833. [CrossRef]

7. Allwood, J.M. Squaring the Circular Economy: The Role of Recycling within a Hierarchy of Material Management Strategies. In Handbook of Recycling: State-of-the-Art for Practitioners, Analysts, and Scientists; Worrell, E., Reuter, M.A., Eds.; Elsevier: Oxford, UK, 2014; pp. 445-477.

8. Yong, R. The circular economy in China. J. Mater. Cycles Waste Manag. 2007, 9, 121-129. [CrossRef]

9. Zhijun, F.; Nailing, Y. Putting a circular economy into practice in China. Sustain. Sci. 2007, 2, 95-101. [CrossRef]

10. Lowe, E. Economic Solutions. In Environmental Solutions; Agardy, F.J., Nemerow, N.L., Eds.; Elsevier: Amsterdam, The Netherlands, 2005; pp. 61-114. 
11. Deus, R.M.; Savietto, J.; Ometto, A.R.; Battistelle, R.A.G. Economia circular ontem e hoje: Uma análise bibliométrica, Ten Years Working Together for A Sustainable Future. In Proceedings of the 6th International Workshop Advances in Cleaner Production, São Paulo, Brazil, 24-26 May 2017.

12. Mativenga, P.T.; Agwa-Ejon, J.; Mbohwa, C.; Sultan, A.A.M.; Shuaib, N.A. Circular Economy Ownership Models: A view from South Africa Industry. Procedia Manuf. 2017, 8, 284-291. [CrossRef]

13. Gregson, N.; Crang, M.; Fuller, S.; Holmes, H. Interrogating the circular economy: The moral economy of resource recovery in the EU. Econ. Soc. 2015, 44, 218-243. [CrossRef]

14. Velis, C. Waste pickers in Global South: Informal recycling sector in a circular economy era. Waste Manag. Res. 2017, 35, 329-331. [CrossRef] [PubMed]

15. Pearce, D.W.; Turner, R.K. Economics of Natural Resources and the Environment; The John Hopkins University Press: Baltimore, MD, USA, 1989.

16. Boulding, K. The Economics of the Coming Spaceship Earth. In Environmental Quality in a Growing Economy; Jarrett, H., Ed.; Resources for the Future/Johns Hopkins University Press: Baltimore, MD, USA, 1966; pp. 3-14.

17. Bauhardt, C. Solutions to the crisis? The Green NewDeal, Degrowth, and the Solidarity Economy: Alternatives to the capitalist growth economy from an ecofeminist economics perspective. Ecol. Econ. 2014, 102, 60-68. [CrossRef]

18. Mauch, C. (Ed.) A Future Without Waste? Zero Waste in Theory and Practice; RCC Perspectives: Transformations in Environment and Society 3; Rachel Carson Center for Environment and Society: Munich, Germany, 2016.

19. Escobar, A. Degrowth, postdevelopment, and transitions: A preliminary conversation. Sustain. Sci. 2015, 10, 451-462. [CrossRef]

20. Coraggio, J.L. Economía Social y Solidária: El Trabajo Antes Que el Capital; Abyla Yala-FLACSO: Quito, Ecuador, 2011.

21. Spash, C.L. New foundations for ecological economics. Ecol. Econ. 2012, 77, 36-47. [CrossRef]

22. Weiss, J.S. The Role of Ecological Economics in Latin American Public Policy: Latin American Consensus at the ISEE Washington Meeting. Ecol. Econ. 2017, 138, 238-241. [CrossRef]

23. Kawano, E.; Miller, E. Building a solidarity economy from real world practices. In Solidarity Economy: Building Alternatives for People and Planet; Allard, J., Davidson, C., Matthaei, J., Eds.; ChangeMaker Publications: Chicago, IL, USA, 2008; pp. 93-100.

24. Álvarez Quispe, J. La economía comunitaria de reciprocidad en el nuevo contexto de la economía social y solidaria: Una mirada desde Bolivia. Otra Econ. 2012, 6, 159-170. [CrossRef]

25. Caruana, M.; Srnec, C. Public policies addressed to the social and solidarity economy in South America. Toward a new model? Voluntas 2013, 24, 713-732. [CrossRef]

26. Laville, J.L. Social and Solidarity Economy in Historical Perspective. In Social and Solidarity Economy: Beyond the Fringe; Utting, P., Ed.; Zed Books: London, UK, 2015; pp. 41-56.

27. Saguier, M.; Brent, Z. Social and Solidarity Economy in South American regional governance. Glob. Soc. Policy 2017, 1-20. [CrossRef]

28. Singer, P. Introdução à Economia Solidária; Fundação Perseu Abramo: São Paulo, Brazil, 2002.

29. Moulaert, F.; Ailenei, O. Social Economy, Third Sector and Solidarity Relations: A Conceptual Synthesis from History to Present. Urban Stud. 2005, 42, 2037-2053. [CrossRef]

30. Moulaert, F.; Nussbaumer, J. Defining the social economy and its governance at the neighbourhood level: A Methodological reflection. Urban Stud. 2005, 42, 2071-2088. [CrossRef]

31. Dinerstein, A.C. The Politics of Autonomy in Latin America: The Art of Organising Hope; Non-Governmental Public Action Series; Palgrave Macmillan: Basingstoke, UK, 2015. [CrossRef]

32. Harris, J.; Codur, A.-M. Macroeconomics and the Environment; Global Development and Environment Institute; Tufts University: Medford, MA, USA, 2004; Available online: http:/ / www.ase.tufts.edu/gdae/education materials/modules/Macroeconomics_and_the_Environment.pdf (accessed on 25 September 2017).

33. Dinerstein, A.C. The Hidden Side of Social and Solidarity Economy Social Movements and the "Translation" of SSE into Policy (Latin America); Occasional Paper 9 Potential and Limits of Social and Solidarity Economy; UNRISD: Geneva, Switzerland, 2014.

34. Gutberlet, J.; Kain, J.-H.; Nyakinda, B.; Oshieng, D.H.; Odhiambo, N.; Oloko, M.; Omolo, J.; Omondi, E.; Otieno, S.; Zapata, P.; et al. Socio-environmental entrepreneurship and the provision of critical services in informal settlements. Environ. Urban. 2016, 8, 205-222. [CrossRef] 
35. Dururu, J.; Anderson, C.; Bates, M.; Montasser, W.; Tudor, T. Enhancing engagement with community sector organisations working in sustainable waste management: A case study. Waste Manag. Res. 2015, 33, 284-290. [CrossRef] [PubMed]

36. Kidd, S.A.; Kral, M.J. Practicing participatory action research. J. Couns. Psychol. 2005, 52, 187-195. [CrossRef]

37. Reason, P.; Bradbury, H. (Eds.) The Handbook of Action Research: Participative Inquiry and Practice, 2nd ed.; Sage: Thousand Oaks, CA, USA, 2008.

38. Prendinger, H.; Ishizuka, M. A creative abduction approach to scientific and knowledge discovery. Knowl. Based Syst. 2005, 18, 321-326. [CrossRef]

39. Hooghe, L.; Marks, G. Unravelling the Central State, but How? Types of Multi-level Governance. Am. Political Sci. Rev. 2003, 97, 233-243.

40. Watson, V. Seeing from the South: Refocusing Urban Planning on the Globe's Central Urban Issues. Urban Stud. 2009, 46, 2259-2275. [CrossRef]

41. Pongrácz, E. Industrial ecology and waste management: From theories to applications. Prog. Ind. Ecol. Int. J. 2006, 3, 59-74. [CrossRef]

42. Scheinberg, A.; Nesić, J.; Savain, R.; Luppi, P.; Sinnott, P.; Petean, F.; Pop, F. From collision to collaboration-Integrating informal recyclers and re-use operators in Europe: A review. Waste Manag. Res. 2016, 34, 820-839. [CrossRef] [PubMed]

43. Gutberlet, J. Urban Recycling Cooperatives: Building Resilient Communities; Routledge Taylor \& Francis Group: Abingdon, UK; New York, NY, USA, 2016; p. 183.

44. Gutberlet, J. More inclusive and cleaner cities with waste management co- production: Insights from participatory epistemologies and methods. Habitat Int. 2015, 46, 234-243. [CrossRef]

45. Gutberlet, J. Briefing: Social facets of solid waste: Insights from the global south. Waste Resour. Manag. 2013, 166, 110-113. [CrossRef]

46. Carenzo, S. Lo que (no) cuentan las máquinas: La experiencia socio-técnica como herramienta económica (y política) en una cooperativa de "cartoneros" del Gran Buenos Aires. Antípoda 2014, 18, 109-135. [CrossRef]

47. Carenzo, S. Desfetichizar para producir valor, refetichizar para producir el colectivo: Cultura material en una cooperativa de "cartoneros" del Gran Buenos Aires. Horiz. Antropol. 2011, 17, 15-42. [CrossRef]

48. Gutberlet, J. Cooperative urban mining in Brazil: Collective practices in selective household waste collection and recycling. Waste Manag. 2015, 45, 22-31. [CrossRef] [PubMed]

49. Gutberlet, J. Gestão de resíduos sólidos. Rev. Geogr. 2013, 30, 6-23.

50. Ninacs, W.A.; Toye, M. A Review of the Theory and Practice of Social Economy/Économie Sociale in Canada; SRDC Working Paper Series 02-02; The Social Research and Demonstration Corporation: Ottawa, ON, Canada, 2002.

(C) 2017 by the authors. Licensee MDPI, Basel, Switzerland. This article is an open access article distributed under the terms and conditions of the Creative Commons Attribution (CC BY) license (http://creativecommons.org/licenses/by/4.0/). 